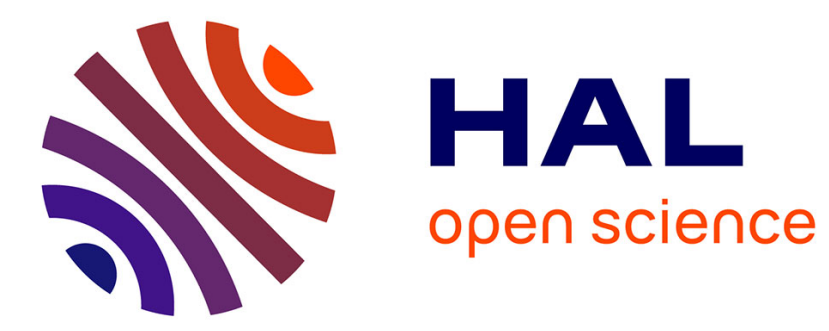

\title{
Chapter 27: Family policies and child well-being
} Lidia Panico, Morgan Kitzmann

\section{To cite this version:}

Lidia Panico, Morgan Kitzmann. Chapter 27: Family policies and child well-being. Handbook on Society and Social Policy, Edward Elgar Publishing, pp.356-371, 2020, Social and Political Science, 10.4337/9781788113526.00035 . hal-03142193

\section{HAL Id: hal-03142193 \\ https://hal.science/hal-03142193}

Submitted on 15 Feb 2021

HAL is a multi-disciplinary open access archive for the deposit and dissemination of scientific research documents, whether they are published or not. The documents may come from teaching and research institutions in France or abroad, or from public or private research centers.
L'archive ouverte pluridisciplinaire HAL, est destinée au dépôt et à la diffusion de documents scientifiques de niveau recherche, publiés ou non, émanant des établissements d'enseignement et de recherche français ou étrangers, des laboratoires publics ou privés. 
This is the original submitted version. The final version is available in $\mathrm{N}$. Ellison and T. Haux (eds.), Handbook on Society and Social Policy, Cheltenham: Edward Elgar. http://dx.doi.org/10.4337/9781788113526.00035

The material cannot be used for any other purpose without further permission of the publisher, and is for private use only.

Full citation:

Panico, L. and Kitzmann, M. (2020) Family policies and their impact on child well-being. In N. Ellison and T. Haux (eds.), Handbook on Society and Social Policy, Cheltenham: Edward Elgar. DOI: 10.4337/9781788113526.00035

\begin{abstract}
In many developed countries, family policies are an established domain of public policy, although the goals and features of these policies vary widely across national contexts and over time. This chapter reviews the key trends in family policies across Europe and examines the literature concerned with the impacts of policies on children, looking at both potential direct and indirect mechanisms of child well-being. The authors focus on the early childhood period. Furthermore, to illustrate indirect effects, they highlight policies that can improve parental well-being (which could, in turn, improve child wellbeing), by reviewing in particular policies supporting parents in reconciling family and professional responsibilities.
\end{abstract}

Keywords: family policies, early childhood education and care, child wellbeing, parental well-being 


\title{
Family policies and child well-being
}

\author{
Lidia Panico and Morgan Kitzmann
}

\section{INTRODUCTION}

In many developed countries, family policies are an established domain of public policy, although the goals and features of these policies vary widely across national contexts and over time. Governments have used family policies to boost fertility rates, facilitate parents' (and in particular mothers') labour market participation, support parents' family-work life balance, and, more recently, invest in children's well-being from the preschool period. These goals are sometimes implicit and may work in combination. Tools to deliver family policies have included a mix of financial incentives (such as tax cuts and transfers), employment and family laws, and service provision; used singularly or in combination. Furthermore, they are often delivered by a plurality of departments, even within a single government. As a result, these policies are a patchwork of different goals, instruments, and providers, although there have been attempts to classify these diverse policies in coherent groupings (Thévenon, 2011). A large body of literature has therefore interested itself in how these policies have developed across time and space, and in particular about their outcomes for families. Given recent interest in the effects of a panel of policies on child outcomes, the focus of this chapter will be on reviewing the available literature on the impact of family policies on children's wellbeing, with an emphasis on the European experience.

As a starting point, it may be necessary to delimit our definitions of 'family' and 'children'. The literature provides several conceptualizations of what is meant by 'family' (Hantrais and Letablier, 1996). In its narrowest sense, a family can be defined as parents and their dependent children; definitions can include the extended family, and, given policy goals such as boosting fertility rates, couples without children. Concerning the definition of chil- dren, here again there are multiple approaches: while usually we refer to dependent minors under the age of $18,0-18$ is a wide age range relating to children benefiting from very different policy instruments. As a result, research often focuses on specific age groups such as the early childhood period, school-aged children, adolescents, young adults, etc., each of which has particular needs and concerns, while remaining influenced by the previous life stages and their impact on future life stages.

Starting from entry into formal schooling, children are direct beneficiaries of longstanding significant public investments through compulsory, formal education systems. The early childhood period, on the other hand, and particularly the 0-3 age period, has received less direct attention (although, through maternity and parental leave, it has long received indirect inputs). This situation has changed rapidly recently, as highlighted by the 2018 G20 meeting, which made early childhood a policy priority and announced thirty-two different initiatives that could be implemented by member states. ${ }^{1}$ This renewed policy focus on early childhood is in line with an expanding literature exploring the importance of investments in early childhood to foster child development and reduce inequalities between groups. These studies have been motivated by longstanding work showing that key cognitive and non-cognitive capabilities develop quickly during the first five years of life, when they are at their most 'malleable' (Nelson, 2000). 
In turn, these skills have been found to be associated with key future outcomes such as educational achievement, health, risky behaviours and labour market outcomes. As result, a number of commentators (see Heckman, 2006, for instance) have argued that interventions in early childhood are fair and profitable public investments.

This chapter is structured as follows: first, we will provide a definition of family policies, with empirical insights on trends of such policies in Europe. Second, we review the literature concerned with the impacts of policies on children, looking at both potential direct and indirect mechanisms of child well-being. Family policies encompass a wide spectrum of instruments, and the literature considering their impacts on families and children is vast. Therefore, to illustrate the effects of these policies on children, we will take policies on early childhood care and education as an example. 'Early childhood' roughly corresponds to the period from birth to entry into formal schooling, which is about age five or six in most European countries. As a life stage, early childhood has been approached through different lenses by different disciplines: as a key phase of human and physical development when individuals acquire language, motor, cognitive, and social and emotional skills; from a sociological point of view, as a phase of primary socialization; and from a public policy perspective, as a stage before compulsory education, when 'school readiness' can be developed. To provide an analysis of how family policies affect global child well-being, this chapter will take an interdisciplinary perspective and consider a range of outcomes. Furthermore, to illustrate indirect effects, we highlight policies that can improve parental well-being (which could, in turn, improve child well-being), by reviewing in particular policies supporting parents in reconciling family and professional responsibilities.

\section{WHAT IS A FAMILY POLICY?}

\section{Policy Instruments for Supporting Families}

In its broadest sense, the notion of family policy encompasses every government policy (whether social, economic, education and so on) having an impact on families. Distinctions can however be made between explicit and implicit family policies, drawing a line between policies directly targeting families, and policies that have indirect effects on families (e.g. employment or pensions policies - see Kamerman and Kahn, 1978). It is also possible to categorize family policies according to whether they focus on couples, parents, children, or society as a whole (Kaufmann et al., 2002), or by their expected outcome. In this chapter, we will focus on explicit family policies targeting parents and their children and evaluate the literature that studies the impact of these policies on a range of individual-level outcomes.

Usually, family policies make use of three instruments, which can vary according to their national and historical context: financial incentives, services for families, and leave allowances. Normally, policies include a combination of these instruments, forming a more or less coherent system. Even when just considering European countries, an enormous variation exists in how these instruments are deployed, including when considering relatively similar objectives. In the case studies in this chapter, we show how differently early childcare policies have been delivered in three European countries (see Box 1 for the UK, Box 2 for Sweden, and Box 3 for France). 


\section{BOX 1: PUBLICLY FUNDED BUT PRIVATELY PROVIDED: UNIVERSAL PRESCHOOL IN THE UK}

The UK is a late adopter of universal publicly-provided early childhood education and care (ECEC), even though it experienced high increases in female labour force participation from the 1960s and 1970s. Education is compulsory from age five, although children can begin school at age four in 'reception' classes, hosted by primary schools. Primary school and reception classes are free. Up until the late 1990s, childcare for children under four was mostly provided by the private sector, providing very heterogeneous levels of services and quality, and funded mostly by parents.

From 1997, the UK government invested substantially in ECEC, with a three-pronged aim of improving the quality of services while increasing both offer and affordability. Spending on ECEC increased three-fold between 1997 and 2008 and enjoyed strong public support. The main instrument was an entitlement to, initially, 12.5 hours a week of free childcare, for 33 weeks of the year, in accredited ECEC centres, for children aged four. This provision has been gradually expanded to all children aged three (from 2001), two-year olds from disadvantaged backgrounds (2013), and, from 2017, three- and four-year olds living in households where both parents work ${ }^{2}$ have seen their entitlement increase to 30 hours per week. Parents can top-up this entitlement by directly paying for extra hours and/ or through 'childcare vouchers' bought through their pre-tax salary, reducing taxable incomes. Parents with low incomes can claim back up to 70 per cent of their direct childcare costs. Extra services incurred during 'free' hours, such as meals, are paid for by parents.

Services are delivered through a fragmented system of private (both for-profit and not-for-profit) and state sector provision. Most of the state offer is for children aged three and over and is school based. In the private sector, parents can often access longer or more flexible opening hours but pay higher fees for any extra hours. These fees are not based on the household's income. Any centre receiving public funds must follow a standardized curriculum, the Foundation Stage. This curriculum emphasizes learning through play and ensures a range of stimulating age-appropriate activities.

The 1997 policy was not accompanied by an increase in the state provision of childcare, so most of the extra demand was met by an expansion of the private sector. Most of the new demand came from disadvantaged families who decreased their use of informal care and increased their use of formal childcare. More advantaged families already enjoyed relatively high use of formal childcare before 1997.

Staff qualifications vary according to sector: in the state sector, as most ECEC programmes are school-based, provision is provided by teachers and nursery nurses, who must hold graduate qualifications. In the private sector, the presence of staff with graduate qualifications is minimal. The 1997 policy did introduce a new vocational qualification in early childhood education and care, increasing slightly the educational profile of ECEC workers. This has not been reflected in the salaries of ECEC workers, which have stagnated since 1997 and remain low, particularly for private sector workers.

\section{Financial incentives}

Financial benefits aim to reduce the direct and indirect costs (opportunity costs) of children to parents. They can take several forms (tax cuts or cash transfers) and can be universal or redistributive by targeting disadvantaged families, and/or can have a specific purpose (e.g. reducing childcare costs) (Bradshaw, 2018; Thévenon, 2009). Figure 1 shows the heterogeneity in this instrument across Europe. 


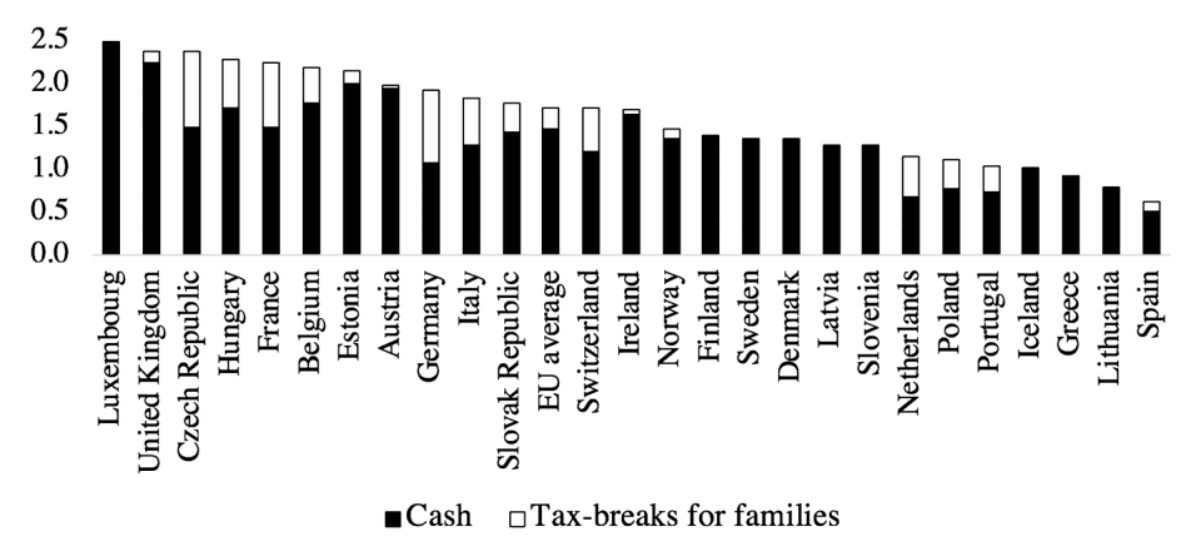

Source: OECD Family Database, http://www.oecd.org/els/family/database.htm.

Figure 1: Public spending on family benefits (\% of GDP in 2015)

\section{Services for families}

Family services generally enable parents to externalize childcare, although they can also include other services such as child-specific health centres or programmes. Education provision past age five/six has clear implications for families but is usually considered as an educational rather than family policy. The OECD provides a typology of childcare and early education services: ${ }^{3}$ (i) Centre-based daycare: collective facilities (nurseries, playschools and parent-run groups) that generally cover the preschool period; (ii) Family daycare: care provided by professional childminders in a home-setting; (iii) Early education programmes: programmes designed to prepare children for school (often school-based). Implementation of these services varies significantly across countries, notably in regard to the type of childcare, quality requirements, opening hours, and starting ages (see case studies).

\section{Leave allowances and work schedule arrangements}

Childrearing requires time. With the increase of women's participation in the labour market, work-life balance has become a key issue for families, especially for mothers (Hochschild, 1990; see Chapter 7 in this volume). Family policies supporting work-family balance include components such as periods of leave, particularly after birth and, increasingly, in the preschool period, for mothers and, to a lesser extent, fathers. While most European countries have legislated for some form of maternity or parental leave, there are variations in the length, flexibility, financial compensation and purpose of these instruments across countries. Several countries have set up shareable parental leave, either reserving a period for fathers (Finland, Iceland, Norway, and Sweden) or granting an extension of the leave period when both parents use it (Germany). These policies aim at promoting gender equity by creating incentives for fathers to take some parental leave, and have been shown to increase uptake of leave by fathers, but with significant social differences (see for example Cools et al., 2015; Geisler and Kreyenfeld, 2011; Kluve and Tamm, 2013 for the German case). Parental leave can be more or less flexible depending on the country, requiring parents to take consecutive days off (for instance, paternity leave in Denmark consists of fourteen consecutive days), or allowing them to choose how to distribute their leave allowance (e.g. Malta). 
Specific work arrangements can also be made available for parents. Parents may be allowed to reduce their work hours by using part-time parental leaves. Flexible work hours, alternative work schedules or remote work arrangements can also help parents reconcile work and family. For instance, in France, mothers of young children working night shifts can request to be reassigned to daytime schedules (Addati et al., 2014). Other parent-specific rights can be granted, such as paid leave for child illness or nursing breaks for breastfeeding mothers in Switzerland, breastfeeding breaks are counted as working hours (Addati et al., 2014).

General employment policies such as paid sick and vacation leave, availability of part-time or flexible jobs can also considered part of the family support packages offered to parents, as they offer a professional context favourable to work-family balance.

\section{BOX 2: THE SWEDISH PRESCHOOL SYSTEM}

There is a longstanding tradition of state-run, universal early education provision in Sweden as part of the welfare state, which also includes generous family benefits such as long parental leave for both parents. 'Early education' includes both nurseries and preschools, with no distinctions between the two, accepting children from about a year old until the beginning of formal schooling at age seven. Attendance is high: 45 per cent of one- to twoyear-olds; 86 per cent of two- to three year olds; 91 per cent of three- to four-year olds; 96 per cent of five- to six-year-olds attend preschool. The vast majority of the sector is state funded, with only about 10 per cent of preschools not funded by the government.

All children from one year of age are guaranteed a place in preschool if their parents are working or studying. Furthermore, all children, irrespective of their parents' employment status, are offered at least 525 free hours from the age of three (known as 'universal pre- school'). Children who do not attend preschool can access 'open preschools' on a part-time basis with their main carer. Parents decide if and when to attend sessions.

The preschool system has a long tradition of regulation and professionalization. About 50 per cent of staff are preschool teachers who have similar qualifications to schoolteachers (university-level education). The rest of the staff is made up of child assistants - a post requiring an upper secondary education qualification. There are no national standards regarding adult-child ratios. These are set by each municipality and vary considerably from one municipality to another. Preschool staff must follow a curriculum set at the national level. The curriculum is designed to promote the child's social, emotional and cognitive development.

Alongside its objective to support children's development and prepare for school, preschools also aim to enable parents to work or study. The proportion of Swedish women with children aged under six in employment is high: 77 per cent of them work, mostly full-time. The preschool system is relatively flexible and accommodates the schedules of working families: daily opening hours are adapted to suit working parents and children can start preschool at different ages and attend for varying numbers of hours a week. 
While the curriculum is set at national level, municipalities are responsible for its implementation, as well as being responsible for funding. They are allowed to charge fees for preschool places beyond the 525 free hours per year; however, there is a maximum fee system: for example, parents with one child pay a maximum of SEK 1,425 (about $€ 135$ ) per month for full-time preschool attendance. Parental fees amount to under 10 per cent of the total preschool costs.

\section{What Are the Aims of Family Policies?}

Family policies can have a number of explicit and implicit aims. Thévenon (2011) lists six main aims: poverty reduction, compensation of economic costs of childrearing, support for employment, improvement of gender equity, support for children's development and fertility dynamism. The balance between these objectives shapes the use of the different instruments described above. For instance, a 2007 German family policy aimed at improving gender equity on the labour market and boosting fertility rates by introducing a short, well-paid parental leave, which could be extended if shared between the parents. This family policy had modest results due to low levels of formal childcare supply that did not allow mothers to reconcile work and family responsibilities (Salles, 2013).

Family policies rarely rely on only one instrument but are usually a set of measures embedded in a particular context, pursuing certain goals. Whether a policy instrument meets its goal may vary according to its context. For instance, the effects of cash benefits on fertility are greater in Nordic European countries compared to other European countries (particularly Southern European countries) due to higher costs of living and a higher supply of childcare services (Luci-Greulich and Thévenon, 2013).

\section{BOX 3: THE FRENCH DAYCARE SYSTEM (CRÈCHE)}

Preschool education has a long tradition in France. Today, the French offer of childcare is diverse and decentralized, with different formal childcare arrangements (childminders, at-home nannies, nurseries), before the universal take up of free public preschool at about age three (école maternelle). About half of under-threes enrol in formal care, either with a childminder or in a daycare centre (crèche). While childminders are predominant, crèches have steadily increased their capacity over the last twenty years, providing places for 16 per cent of preschool children in 2011. The majority of crèches are state-funded and run by the municipality.

Furthermore, families with children under six who need temporary or occasional care may use a halte-garderie. Originally geared towards children whose mothers were not working, haltes-garderies increasingly care for children whose parents work part-time, occasional, and irregular hours. They have expanded faster than standard crèches: the number of places almost tripled over the past twenty years.

While quality is considered to be high, there is no set curriculum for childcare settings. Staff working in a crèche are required to hold relevant state qualifications, differently from childminders (assistantes maternelles), for whom little formal training is required.

Crèches are popular among parents: after birth, 32 per cent of parents report a preference 
for this option. Demand therefore outstrips supply, and regional differences are large, with particularly large disparities between urban and rural areas. Alongside the high cost of daycare provision for small municipalities, this type of expenditure is not necessarily a priority for all rural local authorities.

Due to a limited number of places compared to demand, eligibility is often restricted to children with working parents or those with special educational or social needs; these criteria are set by each municipality. In practice, disadvantaged families do not appear to be prioritized for a place in crèche, although children from a migrant background attend daycare more frequently than those with French-born parents.

\section{WHAT IMPACTS ON CHILD WELL-BEING?}

This section describes the impact of family policies on child well-being. First, we provide an overview of how research and policy has viewed child well-being. Second, we review the extent to which family policies may have a direct impact on child well-being. Finally, we consider indirect impacts on children through effects on family and parental well-being, which are themselves important predictors of child well-being.

\section{What Is Meant by Child Well-Being?}

Research focusing on 'child well-being' usually considers a broad notion covering two aspects: children's concurrent well-being and their long-term trajectories (i.e. short vs. longterm impacts). As the G20 initiative highlights, children are future adults (or adults in the making) and therefore childhood puts in place the first building blocks of adulthood. The G20 initiative aims at enabling and supporting children's development so they can fulfil their full future potential. However, children are not only adults in the making, but they are also 'acting and reflexive subjects' (Engster and Stensöta, 2018, p. 235) and therefore their current well-being also matters, irrespective of what impact it might have on future outcomes.

Research commonly considers several factors as being central for child well-being: for example, housing, material well-being and deprivation; health; cognitive, physical, and socio-emotional development; education and care (Bronfenbrenner, 1979; UNICEF, 2013). Further work has explored more subjective dimensions of well-being such as, for example, the child's self-perceived well-being (life satisfaction) and the quality of their relationships (Bradshaw and Rees, 2017). Throughout this literature, two key concepts are highlighted: multidimensionality (that is, child well-being should not be considered through a single indicator, but seen as a multidimensional concept), and the idea of complementarity (Cunha and Heckman, 2007). Skills complementarity implies that the more one skill or domain of well-being is developed, the more other domains will also improve. Dynamic complementarity suggests that investing or developing skills at a certain age will also have an impact on skills at later ages, making investments at those later ages more efficient. These insights are complementary and suggest that policies are most efficient when they consider child wellbeing holistically and within a life-course perspective. 


\section{The Impact of Family Policies on Child Well-Being}

How do family policies affect child well-being? It is possible to describe two potential sets of mechanisms (see Figure 2). The first mechanism assumes that family policies have a direct influence on child well-being. This would be the case of programmes involving children directly, such as childcare or early education. The second mechanism is indirect: the impact of family policies on children could be mediated by parental and family outcomes, such as parent well-being, their employment status, or household income. Indeed, family policies do not always have an explicit aim to improve child outcomes but are set up at least partly to support parental outcomes such as their labour market participation.

First, we focus on the literature describing the overall impact of policies on children and we then consider indirect impacts through parental or household mediation. Policies aiming to improve child development through early childhood education and care (ECEC) are good examples of how family policies can have a direct influence on children's well-being. James Heckman's work in this field has been influential. Heckman and colleagues have argued that the high returns of ECEC programmes, detailed below, make the early childhood period, before entry into formal schooling systems, the most efficient life stage for policy investment (Heckman and Carneiro, 2003; see Figure 3).

Using longitudinal data following children enrolled in the High/Scope Perry Pre-School programme, based in Ypsilanti, Michigan, USA, studies have provided crucial insights into how ECEC programmes can promote child development, particularly amongst more disadvantaged children. Using a randomized control trial (RCT) approach, the programme provided an active learning environment delivered by highly trained staff, for 2.5 hours per day, over two years, as well as weekly home visits with the parents. Children enrolled in the programme had better educational performances, lower incarceration rates, lower teenage pregnancy rates, and higher earnings in adulthood (Schweinhart et al., 2005), among other outcomes. Financial returns have been exceptional, with estimated returns of over 12 dollars per dollar spent forty years after the programme start (Schweinhart et al., 2005). Furthermore, studies have shown that these positive effects were achieved not through better cognitive skills, but mostly through improved socio-emotional competences such as motivation and autoregulation, particularly for boys (Heckman et al., 2013).

There have been a number of similar ECEC programmes, particularly in the US, since the Perry Pre-School programme was implemented. A review by Karoly et al. (2005) of these small, intensive programmes concluded that targeted early 'prevention' programmes were

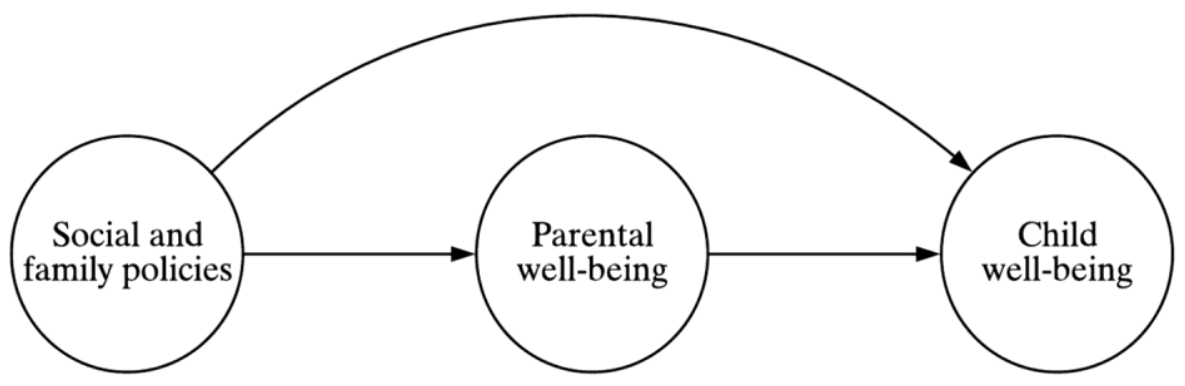

Figure 2: Mechanisms through which family policies may influence child well-being 


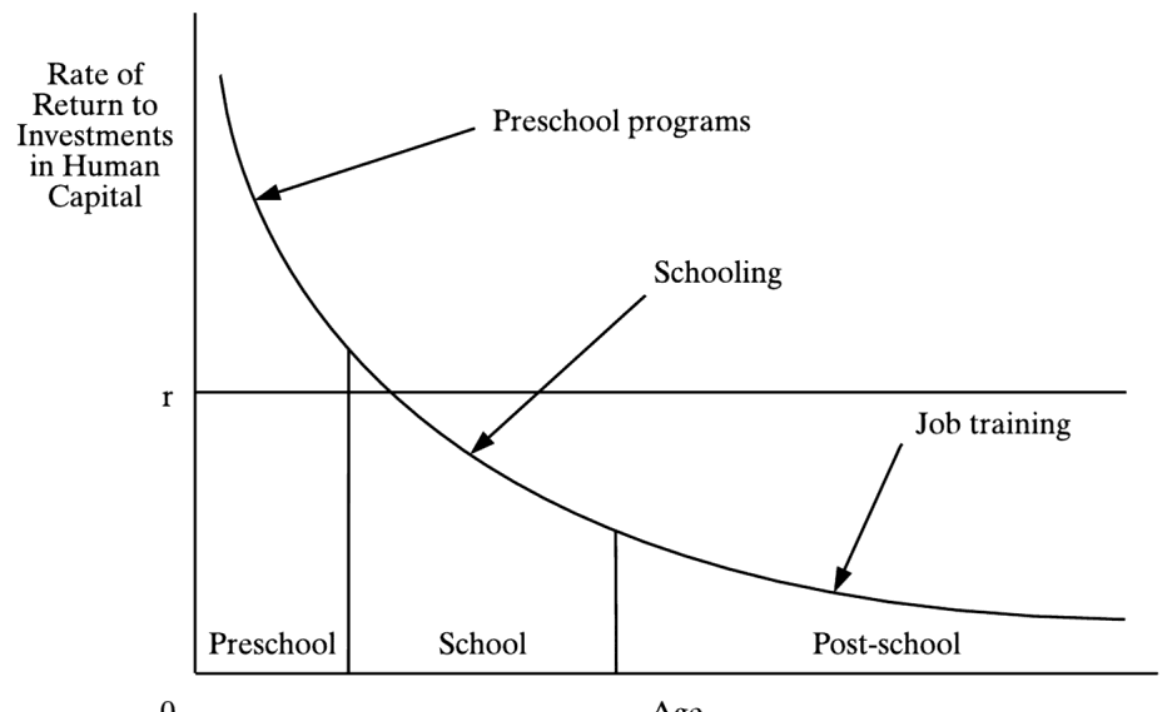

0

Age

Rate of return to human capital investment setting to be equal across all ages

Source: Adapted from Heckman and Carneiro, 2003.

Figure 3: The 'Heckman curve'

effective at reducing inequalities if they provided enriched environments to young children from disadvantaged communities. Positive, long-term outcomes have been noted for cognitive and academic achievement; behaviours such as lower smoking rates; and adult outcomes such as being in employment, higher wages, and lower welfare dependency. There is however a substantial heterogeneity in these effects, as highlighted in a review of RCTs of ECEC interventions aiming at increasing human capital (Fryer, 2017). The review highlighted that these programmes had the largest effects on child outcomes when they directly intervened in children's lives through school or centre-based programmes. Conversely, interventions that attempted to alter the home environment had little or no impact on child development.

The most cited studies therefore have focused on small, intensive, and often experimental programmes, where quality of care is strictly enforced and monitored. Upscaling such intensive and expensive programmes has not been simple and national-level interventions have not always had such significant returns. For example, the Head Start programme started in 1965 in the United States as a summer programme serving 500000 children; today it is a year-long programme serving over 1 million children living in poor households. The programme, funded at federal level but delivered through local agencies, provides an integrated approach offering not only ECEC services but also health interventions and social services. While overall assessments of Head Start have been broadly positive, especially when looking at improvements in parental involvement, child nutrition, and access to services, actual effects on child outcomes have been more mixed. For example, long-term positive effects have been found on cognitive and educational outcomes for White children, but not for Black-African children (Bitler et al., 2014; Garces et al., 2002). No effect on socioemotional outcomes were found (Walters, 2015), which the Perry Pre-School literature has shown to be the key component to long-term positive outcomes. 
Outside of the US, there is less causal evidence about the impact of childcare and early education systems (which, differently from the literature reviewed until now, tend to be universal in European settings). This could be due to several reasons. First, while results appear to be neutral or positive for cognitive, language or socio-emotional outcomes (NICHD, 2005; NICHD and Duncan, 2003), studies on behaviour are more mixed, with some reporting negative or neutral effects (Hansen and Hawkes, 2009; NICHD, 2005; Waldfogel, 2010).

Second, negative results seem to be linked to long hours and/or poor-quality settings (Sylva et al., 2011; Waldfogel, 2010), or to contexts with a large private sector provision of care (which is probably also linked to different quality standards, Blanden et al., 2016). Third, results appear to vary according to child age, particularly with a difference in outcomes for children under age two versus older children (Datar, 2006; Elder and Lubotsky, 2009). This may reflect differential life-course processes but also the different types of services offered at different ages. In most European settings, universally funded and/or provided nurseries and other collective forms of childcare are for children under the age of three to four years, while early education programmes, which usually relate to children aged about three-to-five/six years of age, often offer a bridge between childcare and formal education.

Finally, few studies evaluate the impact of universal, public childcare programmes, possibly because they are more difficult to causally evaluate than small experimental set ups. A notable exception is Gormley and Gayer (2005), which evaluates the Tulsa Pre-Kindergarten programme, a public preschool service open to all children, which started in 1998. They use a regression discontinuity approach exploiting the age cut-off for children to be enrolled in the programme. Findings indicate that attendance at this universal service, described as being of high quality, increased children's cognitive, language and motor skills, although long-term effects only appear to apply to Hispanic children and mainly for cognitive skills (Gormley, 2008). In addition, Felfe et al. (2015) evaluated the effects of the introduction, in the late 1990s, of universal childcare for three-year-olds in Spain on their cognitive outcomes at age 15. Using a difference-in-difference approach, they found an increase in reading and maths test scores following the reform. However, data from Norway offers a more nuanced perspective: while children entering kindergarten earlier did appear to have better cognitive scores in childhood, a lower risk of poor mental health at 18 (for boys), and a lower risk of teen pregnancy (for girls), these effects were very small and there was no impact on educational achievement (Black et al., 2011).

While most early education and care services are provided as stand-alone programmes, a smaller number have aimed to provide integrated services of which childcare and early education are a component among others. The UK Sure Start children's centres, originally installed in more disadvantaged areas but then rolled out nationally, provided childcare alongside various forms of parenting support, health services, links to employment services, information about local services, and early education through drop-in sessions with parental attendance (Sammons et al., 2015). The programme was significantly scaled back from 2010. Research has shown that Sure Start contact was broadly positive for children's cognitive, behavioural and pro-social outcomes, although no impact on children's physical health could be noted. The childcare component was particularly linked to positive child outcomes, while any other centre contact was positively associated with maternal well-being and family functioning (Sammons et al., 2015). 
Nevertheless, centres were not judged to have been successful in meeting complex social or mental health needs.

Beyond impacts of ECEC policies on individual children, can these programmes be used as a tool to reduce population-level inequalities, a key objective of many of these policies? The evidence is again mixed: Felfe and Lalive (2018) estimate the impact of having attended childcare before age two in West Germany using within-state differences in childcare supply as an instrument for childcare attendance. They find that children with low birthweight, and those with younger and less educated mothers, benefit more from childcare, on both language and social skills. Similarly, using data from Norway, Havnes and Mogstad (2011) evaluate the impact of a policy increasing formal preschool attendance on education and labour market outcomes. The policy appeared to have been effective for children in the lower and median part of the earnings distribution, while it was detrimental for those in the higher part of the distribution. These results suggest that, in universal systems, while children from more advantaged backgrounds were already receiving investments from their parents before primary school, and did not benefit from receiving extra external inputs, those receiving fewer initial investments benefited most from these extra inputs.

However, not all studies suggest that more disadvantaged children will benefit more from formal early programmes, particularly in settings with heterogeneous programme quality. For example, in the US, Black African children appear to have benefited less from programmes such as Head Start and the Tulsa Pre-Kindergarten than their White peers (Deming, 2009; Gormley, 2008), and the UK EPPSE study has shown that the most disadvantaged children benefited from formal childcare only if they attended high-quality preschools (Taggart et al., 2015).

\section{Indirect Mechanisms: Parental Well-Being Impacts on Child Well-Being}

As described above, family policies can have a direct impact on children and their well-being. However, state interventions could also have indirect impacts on child well-being through their household's or parents' well-being (see Figure 2). Welfare policies allow a varying degree of decommodification across states; decommodification being defined as the 'degree to which individual, or families, can uphold a socially acceptable standard of living independently of market participation' (Esping-Andersen, 1990, p. 37). Welfare policies can therefore guarantee individuals a certain level of material well-being by ensuring their economic stability and preventing hardship in case of events such as job loss or illness. Similarly, family policies view parenthood as a 'social risk' to manage. Family benefits can directly alleviate the financial strain associated with parenthood; parental paid leave reduces the opportunity costs of time spent in childrearing tasks and guarantees job security; public provision of early education and care allows adults to maintain their participation in the labour market while meeting their family obligations. These policies thus enhance parental material well-being, and possibly also their physical and mental well-being. With this in mind, it is possible to describe three possible consequences of family policies on children that are mediated through parental well-being.

First, household financial resources are determinants of children's living conditions: low incomes may be related to deprivation for children, including poor diets, non-use of medical care, low quality housing conditions, or meeting other basic needs such as clothing (OECD, 2011). Second, research suggests a link between parental stress, their mental health, and parenting practices. Collins and Glass (2018) note that several components of parenthood 
can be sources of stress: first, as parenthood requires time for childrearing, parents are confronted with work-family conflicts; parents report less leisure time, less spousal time, and higher level of exhaustion, which may negatively impact their physical and mental health; second, as parenthood involves direct and indirect financial costs, it can provoke anxiety and stress about financial resources. When experiencing stress or poor mental health, parents are less likely to have quality interactions with their children, which can affect their development and well-being (Votruba-Drzal, 2003). Third, as upper- and middle-class families and working class families have different aspirations and preferences for their children, unavailability of material resources may alter parental educational strategies, parenting practices and therefore child outcomes (Lareau, 2011).

Can family policies help redress these inequalities? Over the last decades, facilitating parents' reconciliation of work and family life has been a key concern of government policy, in tandem with historically increasing trends in female labour force participation and concerns that working parents experience difficulties in balancing professional and family life (Ruhm, 2000), with a negative impact on their well-being, particularly for women. A growing literature has emphasized the benefits of policies that support parents after the birth of a child, particularly maternity leave, for family health and well-being (Avendano et al., 2015; Huerta et al., 2011; Tanaka, 2005). There is less evidence of the impact of family-work policies in the period after maternity leave. Policies have been put forward to allow parents either more flexibility in their jobs or provide longer parental leave. On the one hand, studies have found flexible work arrangements can be positive for family health if parents feel that workplace attitudes towards flexible hours are positive (Eek and Axmon, 2013). On the other hand, no positive correlations have been found in contexts where flexibility is not valued and government policies promoting such arrangements do not provide financial incentives to employers and employees (Avendano and Panico, 2018).

\section{CONCLUSION AND DISCUSSION}

In this chapter, we have reviewed the mechanisms through which family policies can affect children's well-being. Taking into account the multidimensionality of this relationship has been our guiding approach. First, family policies are multidimensional in the sense that they have different goals, are based on a vast diversity of tools (parental leave, financial benefits, service provision), and are intended for a plurality of beneficiaries (parents, children, families as a whole, father-specific, mother-specific, employed parents). Second, child well-being is multidimensional: it covers aspects such as cognitive skills, socio-emotional well-being, school performance, mental health, physical health and motor development. It should therefore not be analysed as a one-dimensional variable but as a multi-faceted phenomenon that needs to be conceptualized holistically. Finally, the mechanisms through which family policies affect children's well-being are also plural and often complementary and should be understood in a dynamic perspective.

As child development and the reduction of inequalities from childhood has become a major concern in public policies in recent years, this chapter has focused on family policies targeting families with a child under six years of age - or directly children under age six. It has consequently left aside several aspects of family policies. For example, as many European countries are among the countries with the lowest fertility rates, demographic dynamism is often an aim of family policies. 
Research has emphasized the difficulties of measuring the impact of policy interventions on the reproductive behaviour of individuals (Thévenon, 2014). In addition to specific goals of family policies not treated in this chapter, it would have been of interest to touch upon family policies targeting age groups other than early childhood, who receive different levels and type of support, depending on the life stage considered and the country involved. Finally, in this chapter we focused on the effects of family policies rather than providing a description of family policies systems across Europe. However, we note a healthy literature aiming at classifying such systems. In line with Esping-Andersen's pioneering work (1990), this work has notably built typologies based on the degree of (de)familialization of family policies in a given country (Bambra, 2004, 2007), which give great importance to worklife balance.

Despite these issues not covered in this chapter, the question of child well-being offers meaningful insights on family policies and their variations across European countries and shows how family policies can address social and gender inequalities, while also interconnecting with social policies in other areas, particularly employment policies.

\section{NOTES}

1. See G20 Initiative for Early Childhood Development: https://www.ecdan.org/assets/g20_initiative _for_early_childhood_development.pdf

2. Each parent also has to earn less than about US\$130,000 per year.

3. OECD Family Database, http://www.oecd.org/els/family/database.htm.

\section{REFERENCES}

Addati, L., N. Cassirer and K. Gilchrist (2014), Maternity and Paternity at Work: Law and Practice Across the World, Geneva: International Labour Office.

Avendano, M., L. F. Berkman, A. Brugiavini and G. Pasini (2015), 'The long-run effect of maternity leave benefits on mental health: evidence from European countries', Social Science \& Medicine, 132, 45-53.

Avendano, M. and L. Panico (2018), 'Do flexible work policies improve parents' health? A natural experiment based on the UK Millennium Cohort Study', Journal of Epidemiology and Community Health, 72 (3), 244-51.

Bambra, C. (2004), 'The worlds of welfare: illusory and gender-blind?', Social Policy and Society, 3 (3), 201-12.

Bambra, C. (2007), 'Defamilisation and welfare state regimes', International Journal of Social Welfare, 16 (4), 326-38.

Bitler, M. P., H. W. Hoynes and T. Domina (2014), Experimental Evidence on Distributional Effects of Head Start (Working Paper 20434), Cambridge, MA: National Bureau of Economic Research.

Black, S., P. Devereux and K. G. Salvanes (2011), 'Too young to leave the nest? The effects of school starting age', The Review of Economics and Statistics, 93 (2), 455-67.

Blanden, J., E. D. Bono, S. McNally and B. Rabe (2016), 'Universal pre-school education: the case of public funding with private provision', The Economic Journal, 126 (592), 682-723.

Bradshaw, J. (2018), 'Family benefit systems', in G. B. Eydal and T. Rostgaard (eds.), Handbook of Family Policy, Cheltenham, UK and Northampton, MA, USA: Edward Elgar Publishing, 84-96.

Bradshaw, J. and G. Rees (2017), 'Exploring national variations in child subjective well-being', Children and Youth Services Review, 80, 3-14.

Bronfenbrenner, U. (1979), The Ecology of Human Development, Cambridge, MA: Harvard University Press. 
Collins, C. and J. Glass (2018), 'Effects of work-family policies on parenthood and wellbeing', in G. B. Eydal and T. Rostgaard (eds.), Handbook of Family Policy, Cheltenham, UK and Northampton, MA, USA: Edward Elgar Publishing, 337-51.

Cools, S., J. H. Fiva and L. J. Kirkebøen (2015), 'Causal effects of paternity leave on children and parents', The Scandinavian Journal of Economics, 117 (3), 801-828.

Cunha, F. and J. J. Heckman (2007), 'The technology of skill formation', American Economic Review, 97 (2), 31-47.

Datar, A. (2006), 'Does delaying kindergarten entrance give children a head start?', Economics of Education Review, 25 (1), 43-62.

Deming, D. (2009), 'Early childhood intervention and life-cycle skill development: evidence from Head Start', American Economic Journal: Applied Economics, 1 (3), 111-34.

Eek, F. and A. Axmon (2013), 'Attitude and flexibility are the most important work place factors for working parents' mental wellbeing, stress, and work engagement', Scandinavian Journal of Public Health, 41 (7), 692-705.

Elder, T. E. and D. H. Lubotsky (2009), 'Kindergarten entrance age and children's achievement impacts of state policies, family background, and peers', Journal of Human Resources, 44 (3), 641-83.

Engster, D. and H. O. Stensöta (2018), 'Family policies and child well-being', in G. B. Eydal and T. Rostgaard (eds.), Handbook of Family Policy, Cheltenham, UK and Northampton, MA, USA: Edward Elgar Publishing, 325-37.

Esping-Andersen, G. (1990), The Three Worlds of Welfare Capitalism, Princeton, NJ: Princeton University Press.

Felfe, C. and R. Lalive (2018), 'Does early child care affect children's development?', Journal of Public Economics, 159, 33-53.

Felfe, C., N. Nollenberger and N. Rodríguez-Planas (2015), 'Can’t buy mommy's love? Universal childcare and children's long-term cognitive development', Journal of Population Economics, 28 (2), 393-422.

Fryer Jr, R. G. (2017), 'The production of human capital in developed countries: evidence from 196 randomized field experiments', in A. V. Banerjee and E. Duflo (eds.), Handbook of Economic Field Experiments, Amsterdam: North-Holland, vol. 2, 95-322.

Garces, E., D. Thomas and J. Currie (2002), 'Longer-term effects of Head Start', American Economic Review, 92 (4), 999-1012.

Geisler, E. and M. Kreyenfeld (2011), 'Against all odds: fathers' use of parental leave in Germany', Journal of European Social Policy, 21 (1), 88-99.

Gormley, W. T. (2008), 'The effects of Oklahoma's Pre-K Program on Hispanic children', Social Science Quarterly, 89 (4), 916-36.

Gormley, W. T. and T. Gayer (2005), 'Promoting school readiness in Oklahoma: an evaluation of Tulsa's Pre-K Program', Journal of Human Resources, 40 (3), 533-58.

Hansen, K. and D. Hawkes (2009), 'Early childcare and child development', Journal of Social Policy, 38 (2), 211-39.

Hantrais, L. and M.-T. Letablier (1996), Families and Family Policies in Europe, London: Longman.

Havnes, T. and M. Mogstad (2011), 'No child left behind: subsidized child care and children's long-run outcomes', American Economic Journal: Economic Policy, 3 (2), 97-129.

Heckman, J. J. (2006), 'Skill formation and the economics of investing in disadvantaged children', Science, 312 (5782), 1900-1902.

Heckman, J. J. and P. Carneiro (2003), Human Capital Policy (Working Paper 9495), Cambridge, MA: National Bureau of Economic Research.

Heckman, J. J., R. Pinto and P. Savelyev (2013), 'Understanding the mechanisms through which an influential early childhood program boosted adult outcomes', American Economic Review, 103 (6), 2052-86.

Hochschild, A. R. (1990), The Second Shift: Inside the Two-Job Marriage, Harmondsworth: Penguin Books.

Huerta, M. del C., W. Adema, J. Baxter, M. Corak, M. Deding, M. C. Gray and J. Waldfogel (2011), Early Maternal Employment and Child Development in Five OECD Countries (OECD Social, Employment and Migration Working Papers 118), Paris: OECD Publishing. 
Kamerman, S. B. and A. J. Kahn (1978), Family Policy: Government and Families in Fourteen Countries, New York: Columbia University Press.

Karoly, L. A., M. R. Kilburn and J. S. Cannon (2005), Early Childhood Interventions: Proven Results, Future Promise, Santa Monica, CA: RAND Corporation.

Kaufmann, F.-X., A. Kuijsten, H.-J. Schultze and C. P. Strohmeier (eds.) (2002), Family Life and Family Policies in Europe, Volume 2: Problems and Issues in Comparative Perspective, Oxford: Oxford University Press.

Kluve, J. and M. Tamm (2013), 'Parental leave regulations, mothers' labor force attachment and fathers' childcare involvement: evidence from a natural experiment', Journal of Population Economics, 26 (3), 983-1005.

Lareau, A. (2011), Unequal Childhoods: Class, Race, and Family Life, Los Angeles, CA: University of California Press.

Luci-Greulich, A. and O. Thévenon (2013), 'The impact of family policies on fertility trends in developed countries', European Journal of Population, 29 (4), 387-416.

National Institute of Child Health and Human Development (NICHD) Early Child Care Research Network (ed.) (2005), 'Early child care and children's development in the primary grades: follow-up results from the NICHD study of early child care', American Educational Research Journal, 42 (3), 537-70.

National Institute of Child Health and Human Development Early Child Care Research Network (NICHD) and G. Duncan (2003), 'Modeling the impacts of child care quality on children's preschool cognitive development', Child Development, 74, 1454-75.

Nelson, C. A. (2000), 'Neural plasticity and human development: the role of early experience in sculpting memory systems', Developmental Science, 3 (2), 115-36.

OECD (2011), Doing Better for Families, https://www.oecd-ilibrary.org/content/publication/ 9789264098732-en.

Ruhm, C. J. (2000), 'Parental leave and child health', Journal of Health Economics, 19 (6), 931-60.

Salles, A. (2013), 'La politique familiale allemande: des difficultés à prendre le virage', Allemagne d'Aujourd'hui, 206 (4), 48-63.

Sammons, P., J. Hall, R. Smees, R. J. Goff, K. Sylva, T. Smith and G. Smith (2015), Evaluation of Children's Centres in England (ECCE). Strand 4: The Impact of Children's Centres: Studying the Effects of Children's Centres in Promoting Better Outcomes for Young Children and Their Families, Report RR495, London: Department for Education.

Schweinhart, L. J., J. Montie, Z. Xiang, W. S. Barnett, C. R. Belfield and M. Nores (2005), The High/ Scope Perry Preschool Study Through Age 40, Ypsilanti, MI: High/Scope Press.

Sylva, K., A. Stein, P. Leach, J. Barnes, L. E. Malmberg and FCCC-team (2011), 'Effects of early child-care on cognition, language, and task-related behaviours at 18 months: an English study', British Journal of Developmental Psychology, 29 (1), 18-45.

Taggart, B., K. Sylva, E. Melhuish, P. Sammons and I. Siraj (2015), Effective Pre-School, Primary and Secondary Education Project (EPPSE 3-16+): How Pre-School Influences Children and Young People's Attainment and Developmental Outcomes Over Time, Research Brief, London: Department for Education.

Tanaka, S. (2005), 'Parental leave and child health across OECD countries', The Economic Journal, 115 (501), F7-F28.

Thévenon, O. (2009), 'Compenser le coût des enfants: quelles implications pour les politiques familiales?', Revue des Politiques Sociales et Familiales, 98 (1), 85-95.

Thévenon, O. (2011), 'Family policies in OECD countries: a comparative analysis', Population and Development Review, 37 (1), 57-87.

Thévenon, O. (2014), 'Évaluer l'impact des politiques familiales sur la fécondité', Informations Sociales, 183 (3), 50-62.

UNICEF (2013), Child Well-Being in Rich Countries: A Comparative Overview, Innocenti Report Card 11, Florence: UNICEF Office of Research.

Votruba-Drzal, E. (2003), 'Income changes and cognitive stimulation in young children's home learning environments', Journal of Marriage and Family, 65 (2), 341-55.

Waldfogel, J. (2010), What Children Need, Cambridge, MA: Harvard University Press. 
Walters, C. R. (2015), 'Inputs in the production of early childhood human capital: evidence from Head Start', American Economic Journal: Applied Economics, 7 (4), 76-102. 